\title{
PROSEDUR PEMERIKSAAN CT SCAN ABDOMEN PADA KASUS KOLESISTITIS DI INSTALASI RADIOLOGI RSUD PROF. DR. MARGONO SOEKARJO PURWOKERTO
}

\section{PROCEDURE EXAMINATION ABDOMEN CT SCAN IN CASE OF COLECYSTITIS AT RADIOLOGY INSTALLATION PROF. DR. MARGONO SOEKARJO PURWOKERTO HOSPITAL}

\author{
Titien Sumarni ${ }^{1)}$, Bagus Abimanyu ${ }^{2)}$, Dartini ${ }^{3)}$ \\ ${ }^{1)}$ Dr. Soedirman Hospital, Kebumen \\ ${ }^{2,3)}$ Health Polytechnics Of Semarang-Indonesia \\ Email : titiensumarni66@ymail.com
}

\begin{abstract}
Background: Have been done research on inspection procedures examination in the case of abdominal CT Scan cholecystitis at Radiology installationProf. Dr. Margono Soekarjo Purwokerto Hospital. This study aims to determine the inspection procedure examination in the case of abdominal CT Scan cholecystitis not using the biphase technique diagnosis and to find out information on examination in the case of abdominal CT Scan cholecystitis with monophase technique at Radiology installationProf. Dr. Margono Soekarjo Purwokerto Hospital.

Methods:This type of research is aqualitaive research case study approach. The data collection methods with unstructured observation , depth interview with 3 radiographers, 1 radiologist, a sending doctor and a patient, and the documentation of the results of reading radiographs and photographs. The data obtained then reduced, classified, dried and then interpreted in the form then concluded kuotasi and suggestions.

Results: The result showed that the procedure examination abdomen ct scan in case of colecystitis at radiology installation Prof. Dr. Margono Soekarjo Purwokerto Hospital before the hearing preparation charge informed consent of patients, perform laboratory checks urium creatinin, fasting from the night and drank appoxcimately $1000 \mathrm{ml}$ of Water the morning before the examination. While the position of the patient supine feet first and the administration of contrast media intra vena with a volume of $80 \mathrm{ml}$ plus $20 \mathrm{ml} \mathrm{Na} \mathrm{Cl}$ and arrangements flow rate 2,0 $\mathrm{ml} / \mathrm{sec}$ with a scan delay of 40 seconds. Reason not to do engenering biphase technique examination in the case of abdominal CT Scan cholecystitis because only monophase technique, arterial phase alone can establish the diagnosis of cholecystitis.

Conclusion: Information on CT Scan diagnosis in Radiology Installation Prof. Dr. Margono Soekarjo Purwokerto Hospital was able to show in indication of cholecystitis but have not been able to show the mass and metastase to the surrounding organs lake the liver gallbladder and pancreas, intrahhepatic and extrahepatic tract.
\end{abstract}

Keywords :Examination of abdominal CT Scan, cholecystitis

\section{PENDAHULUAN}

Kandung empedu adalah organ berbentuk buah pir yang berada di permukaan bawah lobus kanan hati. Dari kandung empedu inilah duktus sistikus yang panjangnya 3 sampai $4 \mathrm{~cm}$, berjalan ke belakang dan ke bawah untuk menyatu dengan duktus hepatikus komunis dan bersama-sama membentuk duktus empedu. Bila empedu yang disekresi oleh hati tidak segera diperlukan untuk pencernaan, maka empedu ini akan melewati duktus sistikus masuk ke kandung empedu dimana keduanya disimpan dan dikonsentrasi. Kapasitas kandung empedu adalah antara $30 \mathrm{dan} 60 \mathrm{ml}$, tetapi akibat kapasitasnya untuk mengabsorbsi air, kandungan empedu di dalamnya menjadi semakin kental. Ketika makanan berlemak memasuki duodenummaka spingter di jalan masuk ke dukuts empedu akan berelaksasi. Kemudian empedu yang disimpan dalam kandung empedu diarahkan ke usus oleh kontraksi dinding kandung empedu (Waston, 2002)

Salah satu penyakit pada kandung empedu adalah kolesistitis yaitu radang kandung empedu. Kolesistitis hampir selalu dihubungkan dengan batu empedu dan terjadi sebagai kondisi akut atau kronis. Kolesistitis sering menyebabkan nyeri abdomen di daerah sebelah kanan hipokondrium. Kolesisititis akut pada umumnya disebabkan karena adanya obstruksi aliran keluar dari kandung empedu oleh batu empedu. Permulaan rekasi radang diakibatkan oleh efek iritasi empedu. Kolesisititis kronik timbul akibat terjadinya kolesistisi akut yang berulang-ulang. Dinding kandung empedu menebal akibat fibrosis dan secara relative menjadi kaku (Underwood, 1994)

Infeksi pada kandung empedu terjadi melalui penyebaran kuman secara hematogen dari sumber infeksi di bagian lain tubuh, misalnya tonsillitis, sinusitis dan lain-lain. Dapat juga ditemukan infeksi akibat refluks cairan lambung atau cairan pancreas ke dalam kandung empedu. Pada kolesistitis emfisematus terbentuk gas di dalam kandung empedu, dinding kandung empedu atau pada keduanya. Infeksi ini lama kelamaan akan menyebar ke dalam duktus-duktus kandung empedu (Rasad, 1999)

Salah satu pemeriksaan pada kandung empedu adalah pemeriksaan CT Scan. Biasanya CT Scan berfungsi sebagai modalitas pencitraan awal untuk evaluasi dari abdomen akut. CT Scan juga merupakan teknik yang lebih disukai untuk mendiagnosa komplikasi kolesisititis akut. Pada CT Scan akan tampak batu empedu, penebalan dinding kandung empedu, empedu hiperatinuating dan cairan pericholecystic (Sebastian dan Rendon, 2006) 
Menurut Sebastian dan Rendon (2006), radang pada kandung empedu atau kolesistitis akan tampak pada pemeriksaan CT Scan dengan fase vena portal dengan waktu delay 60-70 detik setelah penyuntikan media kontras. Pada fase vena portal merupakan fase yang tepat untuk visualisasi dan evaluasi saluran empedu intrahepatik, ketika ada perbedaan atenuasi terbesar antara parenkim hati dan hipoatenuasi saluran empedu. Eva,uasi dari dinding kandung empedu pada kasus kolesistitis tampak pada fase arteri dan fase vena portal. Pada fase arteri waktu delaynya sekitar 20-35 detik setelah penyuntikan media kontras. Lapisan dalam pada dinding kandung empedu telah mengalami isoatenuasi selama fase arteri dan fase vena portal.

Di Instalasi Radiodiagnostik RSUD Prof. Dr. Margono Soekarjo Purwokerto untuk pemeriksaan CT Scan abdomen dengan kasus kolesistitis dilakukan dengan pemeriksaan CT Scan abdomen rutin. Pemeriksaan ini dilakukan dengan teknik satu fase yaitu fase arteri dengan waktu delay 40 detik setelah pemasukan media kontras. Radang pada kandung empedu atau kolesistitis akan dapat diperlihatkan pada fase arteri karena kolesistitits biasanya disebabkan oleh adanya batu kandung empedu.

Dari paparan di atas dengan melihat adanya perbedaan prosedur pemeriksaan CT Scan abdomen dengan kasus kolesistitis di Instalasi Radiodiagnostik RSUD Prof. Dr. Margono Soekarjo Purwokerto dan dengan literature yang ada, penulis ingin mengetahui lebih lanjut apakah prosedur pemeriksaan CT Scan abdomen dengan kasus kolesistitis di Instalasi Radiodiagnostik RSUD Prof. Dr. Margono Soekarjo Purwokerto sudah efektif dalam mendiagnosa kelainan yang ada.

\section{METODE}

Penelitian ini merupakan penelitian kualitatif dengan pendekatan studi kasus. Pengambilan data untuk melengkapi penelitian ini dilaksnakan di Instalasi Radiodiagnostik RSUD Prof. Dr. Margono Soekarjo Purwokerto pada bulan Mei 2012 sampai Juli 2012.

Penelitian dilakukan dengan cara observasi, wawancara dengan 3 orang radiografer, 1 orang dokter spesialis radiologi, 1 orang dokter pengirim dan 1 orang pasien di Instalasi Radiodiagnostik RSUD Prof. Dr. Margono Soekarjo Purwokerto. Analisis data dilakukan dengan membuat koding terbuka kemudian dapat diambil suatu kesimpulan.

\section{HASIL}

Prosedur Pemeriksaan CT Scan Abdomen Pada Kasus Kolesistitis di Instalasi Radiodiagnostik RSUD Prof. Dr. Margono Soekarjo Purwokerto

\section{Persiapan Pasien Sebelum Pemeriksaan}

Melakukan cek laborat ureum kreatinin, mengisi blangko inform consent, puasa dari malam hari sebelum pemeriksaan, dan pasien minum air putih sebanyak 1 botol besar kira-kira $1000 \mathrm{ml}$ pagi harinya sebelum pemeriksaan. Persiapan alat dan bahan alat radiografi dan persiapan bahan media kontras.

Teknik Pemeriksaan
Posisi pasien supine feet firsttidur terlentang di atas meja pemeriksaan dengan posisi kaki dekat dengan gantry danMid Sagital Plane (MSP) tubuh pasien sejajar dengan lampu indikator longitudinal.

Teknik pemasukan media kontras secara bolus intra vena dengan single injektor. Pasien datang sudah terpasang abbocath no 20 kemudian pasang konektor yang terhubung dengan injektor otomatis dengan media kontras yang digunakan $80 \mathrm{ml}$ dan $\mathrm{Na} \mathrm{Cl} 20 \mathrm{ml}$ dan pengaturan flow rate $2,0 \mathrm{ml} /$ detik. Sebelumnya pasien dilakukan tes alergi media kontras dengan memasukkan media kontras sebanyak 1-5 ml ditunggu selama 5 menit apabila tidak ada reaksi alergi maka pemeriksaan dilanjutkan.

Teknik scanning dilakukan dengan pemilihan protokol pemeriksaan Abdomen Routine RSMS yaitu scan topogram, Scan abdomen routine non kontras, dan scan abdomen routine kontras mediadengan scan delay 40 detik setelah pemasukan media kontras pada fase arteri.

\section{Proses Rekonstruksi Gambar}

Recon 1 abdomen routine non kontras dilakukan rekonstruksi dengan mengubah slice thikness lebih tipis menjadi $2,5 \mathrm{~mm}$.

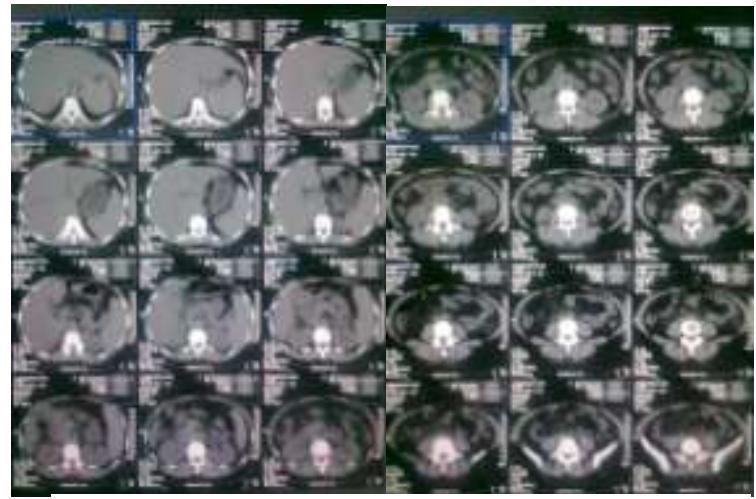

Gambar1. Potongan axial abdomen routine non kontras

Recon 2 abdomen routine kontras media dilakukan rekonstruksi dengan mengubah slice thikness lebih tipis menjadi $2,5 \mathrm{~mm}$.

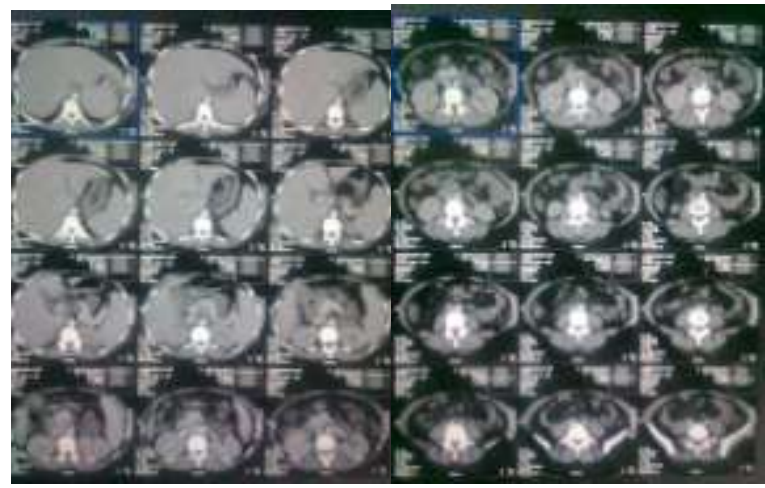

Gambar 2. Potongan axial abdomen routine kontras media

Recon 3 rekonstruksi potongan coronal dari scanning axial abdomen routine kontras media dengan menggunakan 3D MIP Thin dan slice thikness $6 \mathrm{~mm}$ 


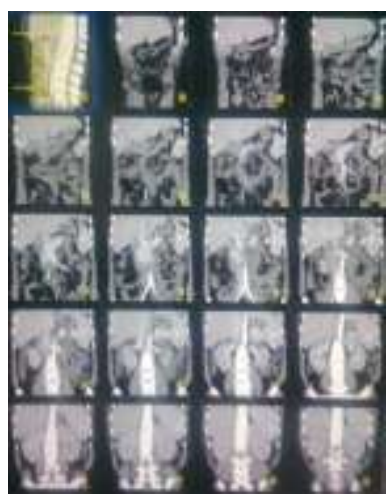

Gambar 3.Potongan coronal abdomen routine kontras media

\section{Prosesing Film}

Proses pencetakan film menggunakan dry view dicetak 3 lembar yaitu axial abdomen routine 1 lembar, axial abdomen routine kontras media 1 lembar dan coronal abdomen routine kontras media 1 lembar.

\section{Hasil Pembacaan Radiograf}

Cenderung adanya gambaran kolesistitis. Tak tampak kelainan lainnya pada pemeriksaan CT Scan abdomen.

Alasan prosedur pemeriksaan CT Scan abdomen pada kasus kolesistitis tidak menggunakan teknik 2 fase (biphase) karena hanya dengan satu fase saja fase arteri sudah dapat menegakkan diagnose kolesistitis sehingga tidak perlu dilakukan scanning fase vena karena beban pesawat akan tinggi, dosis radiasi yang diterima pasien juga bertambah tinggi, biaya pemeriksaan akan bertambah mahal dan waktu pemeriksaan akan menjadi lebih lama. Sedangkan teknik 2 fase (biphase) digunakan untuk melihat kelainan pada hepar dan organ selain daerah kandung empedu juga untuk melihat komplikasi pada hepar atau pancreas yang berdampak pada kolesistitis.

Informasi diagnosis yang dapat diperlihatkan pada pemeriksaan CT Scan abdomen pada kasus kolesistitis dengan menggunakan tehnik satu fase, fase arteri yaitu tampak enhancement dinding kandung empedu ada penebalan/tidak, permukaan dinding kandung empedu rata/kasar, tampak batu kandung empedu, tampak cairan pericholecystic.Apabila ada bendungan pada saluran kandung empedu bisa disebabkan oleh batu atau massa pada caput pancreas. Namun untuk melihat adanya massa pada caput pancreas harus dilakukan teknik 2 fase, yaitu fase arteri dan fase vena.

\section{DISKUSI}

Menurut Sebastian dan Random (2006), pada kasus kolesistitis fase vena merupakan fase yang tepat untuk visualisasi dan evaluasi saluran empedu intrahepatik. Untuk evaluasi dari dinding kandung empedu tampak pada fase arteri dan fase vena. Lapisan dinding kandung empedu telah isoatenuating selama fase arteri dan fase vena.

Sedangkan prosedur pemeriksaan CT Scan abdomen pada kasus kolesistitis di Instalasi Radiodiagnostik RSUD Prof. Dr. Margono Soekarjo Purwokerto menggunakan teknik satu fase yaitu fase arteri.
Menurut penulis pemeriksaan CT Scan abdomen dengan kasus kolesistitis sebaiknya menggunakan tehnik 2 fase (biphase) karena selain untuk memperlihatkan adanya kolesistitis yang disebabkan oleh obstruksi karena adanya batu pada kandung empedu dan saluran kandung empedu, dengan dilakukannya scanning fase vena maka akan dapat memperlihatkan penyebab dari obstruksi yang dikarenakan oleh adanya massa pada hepar atau pada caput pancreas dan juga dapat melihat kelainan-kelainan pada duktus intrahepatik maupun ekstrahepatik sehingga diagnose penyakit dapat ditegakkan.

\section{SIMPULAN}

Prosedur pemeriksaan CT Scan abdomen pada kasus kolesistitis di Instalasi Radiodiagnostik RSUD Prof. Dr. Margono Soekarjo Purwokerto, persiapan pasien sebelum pemeriksaan melakukan cek laborat ureum kreatinin, mengisi blangko inform consent, puasa dari malam hari sebelum pemeriksaan, dan pasien minum air putih sebanyak $1000 \mathrm{ml}$ pagi harinya sebelum pemeriksaan. Sedangkan posisi pasien yang digunakan supine feet first karena untuk memudahkan dalam memantau keadaan umum pasien. Untuk pemberian media kontras intra vena $80 \mathrm{ml}$ ditambah dengan $20 \mathrm{ml} \mathrm{Na} \mathrm{Cl}$ dan pengaturan flow rate $2,0 \mathrm{ml} /$ detik dengan waktu delay scan 40 detik.

Alasan prosedur pemeriksaan CT Scan abdomen pada kasus kolesistitis tidak menggunakan tehnik 2 fase (biphase) karena hanya dengan satu fase, fase arteri saja sudah cukup untuk menegakkan diagnosa kolesistits.

Informasi diagnosis pada pemeriksaan CT Scan abdomen dengan kasus kolesistitis di Instalasi Radiodiagnostik RSUD Prof. Dr. Margono Soekarjo Purwokerto sudah dapat memperlihatkan adanya indikasi kolesistitis dengan ditandai adanya penebalan dinding kandung empedu namun belum dapatmemperlihatkan adanya massa dan metastase pada organ sekitar kandung empedu seperti pada hepar, pankreas dan saluran intrahepatik maupun ekstrahepatik.

\section{DAFTAR PUSTAKA}

Rasad, S. 2000. Radiologi Diagnostik. Balai Penerbit FKUI, Jakarta.

Sebastian, T.S and Rendon, C.N. 2006. MDCT A Practical Approach, Hepatobiliary Imaging by Multidetector Computed Tomography $(M D C T)$. Springer Verlag, Italia

Sutton, D. 1980. A Textbook of Radiology and Imaging. Churcill Livingstone, London.

Underwood, J.C.E. 1994. Patologi Umum dan Sistematik (General and Systematic Phatologhy). EGC, Jakarta.

Watson, R. 2002. Anatomi dan Fisiologi, Edisi 10. ECG, Jakarta. 